Urban Policy and Research,

Vol. 24, No. 1, 39-52, March 2006

Routledge

Taylor \& Francis Croup

\title{
Discourse Analysis and its Utility for Urban Policy Research
}

\author{
KEITH JACOBS
}

ABSTRACT In recent years, discourse analysis has been deployed by academics as a methodology to understand the urban policy implementation process, in particular, the ways in which key actors exercise power. Much of the discourse-based research in urban policy has drawn upon the writings of Norman Fairclough and Michel Foucault and seeks to provide a critical scrutiny of texts and utterances of policy makers and other key actors. The methodological assumption that informs discourse-based approaches is that politics is an arena in which different interest groups seek to establish a particular narrative or version of events as a means to pursue political objectives. This article begins by setting out the theoretical influences that have informed discourse analysis. There then follows a discussion of some of the studies that have deployed discourse-based research within urban policy, an evaluation of its strengths and weaknesses as a method and an assessment for new areas of enquiry. The article's conclusion is that discourse analysis provides the researcher with a set of tools to interpret urban policy in a theoretically informed and insightful way. However, there are some pitfalls associated with its techniques that require consideration before any analysis should commence.

KEY WORDS: Discourse analysis, urban, policy, Foucault, Fairclough

\section{Introduction}

It is evident from even the most cursory glance through some of the recent journals on urban policy that many more research articles deploying the methods associated with discourse analysis ${ }^{1}$ are being published. In recent years, articles with a discourse analysis component have appeared in journals such as Urban Studies, ${ }^{2}$ Housing Studies, Housing Theory and Society, Environment and Planning and Cities. Yet, the proliferation of discourse analysis in urban policy research has also been accompanied by a cacophony of criticism from the policy community and some academics who view much of the discourse-based research corpus as unsystematic and adding little to the evidence base (e.g. Parker \& Burman, 1993; Antaki et al., 2002). This disjuncture, between the increasing output of research informed by discourse analysis and its hostile reception from some quarters, is a good reason to take stock and evaluate its utility. ${ }^{3}$ The extent to which discourse analysis can provide insight and the degree to which criticism of it is justified is the focus of this article.

There are two substantive reasons as to why discourse analysis is often utilised in the field of urban policy and other applied social science disciplines. First,

Correspondence Address: Keith Jacobs, School of Sociology and Social Work, University of Tasmania, Private Bag 17, Hobart 7001, Australia. Email: Keith.jacobs@utas.edu.au

0811-1146 Print/1476-7244 Online/06/010039-14 (C) 2006 Editorial Board, Urban Policy and Research DOI: $10.1080 / 08111140600590817$ 
an acknowledgement that research that focuses exclusively on the decision-making process can be too narrow or myopic. The merit of traditional policy research is its uncovering of the role of bureaucratic modes of organisation, managerial and implementation practices, yet it has been less successful in providing an analysis of some of the power and ideological conflicts that influence the deliberation of policy implementation (Stone, 1988; Fischer \& Forester, 1993; Hastings, 1998; Jacobs, 1999).

Second, researchers increasingly recognise the important role of language in the policy arena. Academics who have deployed discourse analysis maintain that a study of language can provide significant insights that are not always evident from other research methodologies. These insights accrue particularly from scrutinising some of the ways in which language is used to pursue political and organisational objectives as well as how policy documents are interpreted by their intended audience. It is argued that a close examination of language in the form of utterances and texts can provide a richer and more nuanced understanding of the policy process than is possible from more traditional methods or techniques. As Fairclough et al. (2004) explain, "people not only act and organize in particular ways, they also represent their ways of acting and organizing, and produce imaginary projections of new or alternative ways, in particular discourses" (p. 2). The way in which actions are represented in language is therefore of crucial interest.

\section{Influences upon Discourse-Based Methodologies in Urban Policy Research}

Before examining some recent examples of discourse-focused research it is expedient to explore some of the influences that have informed discourse analysis. Hastings (1999) traces the interest in discourse analysis in the field of urban policy research to the "spawning sub-discipline of cultural geography which, since the early 1980s, has been engaged in exploring the contested meanings that are a feature of city life" (p. 8). For Hastings, discourse analysis has been informed by the work of cultural geographers who have sought to understand the representation of spatial phenomena in literature, art and the iconography of the city - that is, the symbolic impact of the built environment and cityscapes on social life. Though there can be no doubt that the work of cultural geographers has been of importance there are other formative influences too. For example, worthy of citation are the linguistic philosophies of Wittgenstein (1974) and Winch (1977) and the writings of the political scientist William Connolly (1983), all of whom emphasised the performative aspects of language. For Wittgenstein and Winch, since the meaning of words is always expressive and inseparable from practice, it was necessary to focus on language to understand more fully the complex ways in which human agents interpret their environment. For Connolly (1983), the language of politics is "an institutionalised structure of meaning that channels political thought or action in certain directions" (p. 1). His perspective had a significant impact on political science in that it encouraged researchers to see language not as a conduit for concepts or ideas but as a political activity in its own right. ${ }^{4}$ The work of Connolly has spurred academics to view policy language in an altogether different light and to question the long held assumption that policy language is a neutral medium in which ideas and an objective work can be both represented and discussed. 


\section{Recent Examples of Urban Policy Research that have Used Discourse Analysis}

There is no better way of assessing the merits of discourse-based approaches in urban policy research than to explore some of the articles from this corpus. However, before doing so, it is helpful to distinguish between different approaches that are commonly deployed by academics utilising discourse analysis. Lees (2004) identifies two strands of discourse analysis within the field of urban policy research: political economy informed analysis and Foucauldian-inspired research. The first emanates from some of the Marxist writings of the late 1970s that extolled the significance of ideology and political economy in enabling powerful vested interest groups to impose hegemony. For Lees, this strand includes the methods associated with Norman Fairclough known as 'critical discourse analysis' as well as the study of 'discourse coalitions' advanced by writers such as Dryzek (1993), Fischer and Forester (1993), Hajer (1993), Davoudi and Healey (1995), Newman (1996) and Rydin (1998). Such commentators have sought to establish the linguistic strategies that are deployed by key actors to shape policy agendas (see Harrison et al., 2004 for a recent example from this perspective). Though Lees does not mention them, the work of Laclau and Mouffe (1985) also requires some acknowledgement. Their work emphasises the significance of political conflict in shaping discursive practices and it has been influential for researchers interested in charting the impact of political ideologies such as Thatcherism and neo-liberalism at a macro-level (e.g. Hall, 1988). However, Laclau and Mouffe do not seek to interrogate specific texts in detail; instead their focus is on the interconnections between different ideological discourses. Their work is also highly theorised and written at a level of abstraction which may explain why their work has had only limited impact on investigations examining specific aspects of the urban policy process. ${ }^{5}$

The second strand identified by Lees is work that draws upon the historical writings of Michel Foucault (Foucault, 1972, 1980, 1991). Lees argues that Foucauldian-inspired discourse analysis advances a view that language plays an instrumental role in establishing 'regimes of truth' (Foucault, 1980) by which social problems are formulated and addressed. Discourse analysts, writing from a Foucauldian perspective, claim that power is not reducible to individual agency but is instead constituent of a network of relations. In other words, the exercise of power is contingent on the relationships formed between individuals within and beyond organisations. The second important component of a Foucauldian approach is the emphasis upon the recursive relationship between language and power rather than seeing language as simply a reflection of power relations. Therefore, language practices both shape and are shaped by power relations. Work that has drawn from Foucault very often adopts a historical approach by setting out how regimes of truth are articulated and reveal evidence of contradictions or ruptures in the text which may be evident, albeit less explicitly. There are examples that provide an explicit rationale for the approach (Atkinson, 1999; Stenson \& Watt, 1999; Sharp \& Richardson, 2001) whilst others such as Vagnby and Jensen (2002) overlook this. ${ }^{6}$

The argument advanced by Lees (2004) that a distinction can be made between two discourse-based research approaches is certainly helpful for situating the most influential modes of critical discourse methodologies. However, it is necessary to mention some other variants of discourse-based research that fall outside of Lees' typology yet have some relevance for urban policy research. In particular, some acknowledgement should be made of the linguistic and ethnomethodological strands of discourse analysis that have been developed by social psychologists. Notably those associated with the 'Discourse and 
Rhetoric Group' in the Department of Social Sciences at Loughborough University in the UK (e.g. Billig, 1995; Potter, 1996, 2003; Edwards, 1997; Antaki et al., 2002) alongside the work of Wetherell et al. (2001). Discursive psychology focuses on the actor's interpretations and how these are produced in discourse. The methods of discursive psychology have been used successfully to analyse transcriptions of conversations so researchers interested in analysing, in detail, data gathered from interviews are likely to find this mode of analysis particularly useful.

\section{Discourse Analysis Informed by Political Economy}

Clearly, if discourse analysis is to be valued in the area of urban policy, it will be incumbent on researchers to be explicit about the techniques deployed. One of the advantages of utilising Fairclough's approach $(1989,1992,1995)$ is that it provides a clear analytical structure for engaging in discourse analysis. Fairclough adopts a threedimensional framework:

- text analysis - this entails the study of the structure of text, vocabulary and grammar cohesion;

- discursive practice - this involves the analysis of the processes in which texts are framed, that is, the context in which statements are made and feed into other debates; and

- social practice - this requires a study of discourse in relation to wider power structures and ideology.

Together the framework links three analytical traditions to exhibit the inter-connections between policy texts and broader political change. Those who have used Fairclough's approach have sought to reveal how language is deployed to legitimise action and structure the parameters of policy intervention (Jacobs \& Manzi, 1996; Jackson, 1999; Taylor, 1999; Jacobs, 2004).

The research within the corpus draws both on discourse and on the wider economic and political context. Collins (2000), for example, provides a detailed case study of trade union opposition to the closure of the shipyards in Glasgow, Scotland, during the early 1970s. His study provides a richly informed sociological account of the background to the dispute by using discourse analysis to scrutinise text in close detail. Unusually for a discourse analyst within the urban studies corpus, Collins draws upon the Russian writer Volosinov (1986), whose emphasis is on the value judgements that are embedded in utterances and texts (see Collins, 1999) and argues that discourse analysis is linked to a form of political economy that can provide a valuable methodological approach to understand policy change.

Marston (2002) provides a valuable discussion of the challenges that arise in using critical discourse analysis in the study of housing policy processes. Marston embraces Fairclough's approach, suggesting it can be deployed "to illustrate how 'ideological cues' work to facilitate policy change" (p. 88). For Marston, ideological discourses are often used by actors within organisations to promote specific policy agendas that are commensurate with their interests. Yet Marston raises some concerns about Fairclough's version of critical discourse analysis. In particular, Marston argues that the use of critical discourse analysis is not sufficient on its own to capture adequately the complexity of the policy process. He maintains that additional qualitative and ethnographic techniques 
are also required alongside an analysis of discourse to more fully account for contemporary developments in housing and urban policy. Other criticisms about the application of discourse analysis are returned to later on in the article.

More recently, Marston (2004a, b) has drawn upon critical discourse analysis to discuss the impact of market-inspired changes during the latter part of the 1990s, in the management and provision of public housing in Queensland. Marston's focus is on what he terms 'managerial subject positions'. These are the sets of beliefs or assumptions that actors working with housing departments adhere to. In the case of Queensland's housing department, Marston argues that, on the one hand, some policy actors who were opposed to the implementation of market-based reforms sought to align their subject positions with more oppositional ideological discourses and the perspectives of disadvantaged tenants. On the other hand, there were actors who embraced public housing reforms, yet were reluctant to accept the concept and practice of new managerialism. A key strength of Marston's recent work is that, by focusing on the specific details of management practices, he is able to excavate the subtleties that are so often ignored from more structurally based approaches to policy changes. He also seeks to counter one of the principal objections to discourse-informed analysis by writers such as Imrie et al. (1996) and Lees (2004), that discourse analysis has little practical relevance to those seeking to change urban policy practices. Marston (2004a) explicitly focuses on what he calls 'sites of resistance', where individuals challenge "colonising discourses, inequalities and hierarchical power relations in organisational settings" (p. 18) in an attempt to counter the criticism that discourse analysis has no clear practical utility.

Other contributions worthy of mention include Arapoglou's (2004) study of the governance of homelessness in Greece. Arapoglou compares key policy texts and interviews with policy actors to reveal how both philanthropic and managerial discourses are deployed by government agencies to justify their interventions in the delivery of services to homeless people. The issue of homelessness is the subject of another discoursebased analysis undertaken by Klodawsky et al. (2002). Their research deploys a content analysis of media portrayals of homelessness in the Ottawa Citizen newspaper in Canada. Their analysis highlights how systemic issues relating to the causes of homelessness are downplayed at the expense of more pathological interpretations and how, in turn, this discourse is used to justify policies that distinguish between the deserving and undeserving poor.

Skillington (1998) also provides another good example of the contribution that can be made by discourse-based methods. In his study, he uses a textual oriented analysis drawing upon Fairclough to examine the redevelopment of Dublin's city centre. Skillington argues that symbolic and referential discourses have created an insular hegemonic paradigm that promotes a tight demarcation of public and private space, thereby making it difficult to establish progressive or alternative visions of urban renewal. Drawing upon an evidence base of articles in the Irish Times newspaper in the early 1990s, he examines how structural power relationships are reinforced through narratives relating to urban redevelopment.

\section{Foucauldian-Inspired Analysis}

While writers such as Arapoglou (2004) and Marston (2004a\&b) have utilised discourse analysis to explore in detail the machinations of organisational practices, others have 
deployed a discourse analysis in a broader setting by taking an explicitly historical approach that draws upon the work of Michel Foucault $(1971,1974,1977,1980)$. One of the key claims advanced by Foucault is that discourses can be viewed as a complex set of competing ideas and values, all of which are actualised in our everyday practices and that the key task for researchers is to identify how discourses exemplify conflicts over meaning that are linked to power. For Foucault, discourse plays a pivotal role in establishing what he terms 'regimes of truth', that is, the grounds from which we assert understandings about the social world. For Foucauldian-inspired scholarship, our understandings of politics are subject to historical shifts that are contingent on the diffuse ways that power is exercised.

Writers within the urban policy tradition who have embraced Foucauldian methods such as Richardson (2004) and Sharp and Richardson (2001, p. 196) interpret discourses as "a multiple and competing set of ideas and metaphors embracing both texts and practices". They argue that changes in discourses are the outcome of power conflicts in which different groups vie to impose their agenda, rather than of a rational, deliberative set of events. Within an Australian context, Dean (1999) has examined how neo-liberal discourses have incorporated aspects of welfare-oriented language as a means of securing greater legitimacy. This appropriation of more social forms of governance is an aspect of contemporary politics where Foucauldian scholarship has made an important contribution. The claim made is that discourses establish regimes of truth that to a large extent determine the acceptable formulations of problems and their solution. Within this paradigm, texts are construed as representing a body of statements that perform a number of functions, for example, rhetorical, legitimising and synthesising activities.

Robert Beauregard (1993) has been influential amongst Foucauldian-inspired writers in the urban studies field. Beauregard takes an historical approach to the city from the 19th century to the current era to chart how North American cities have been represented and how, in turn, this representation has informed policy discourses and popular understandings of the city. For Beauregard, texts are instrumental in creating narratives of urban decline and his work has influenced a number of recent discursive approaches to the city (see Boyle \& Rogerson, 2001 for a discussion).

The influence of Foucault is evident in the work of Stenson and Watt (1999) and Mele (2000). Stenson and Watt draw upon Foucault to examine two local government economic regeneration texts produced by policy makers in the UK in the late 1990s. They argue that proponents of neo-liberal policies have successfully incorporated the language of social democratic discourse in order to secure greater legitimacy with the wider public. The focus of Mele's (2000) article is the symbolic representations of the city and how these inform 20th-century accounts of urban change. Mele uses stakeholder perceptions to show how wider discourses relating to the city can facilitate a benevolent and normalising view of major urban restructuring. In particular, Mele examines how powerful discourses of poverty and urban decay acted as a break on rational planners' aspirations to redevelop New York's Lower East Side following the economic depression of the 1930s.

Parker's (2000) article "Tales of the City: Situating Urban Discourse in Place and Time" is typical of some of the many Foucauldian-inspired works inspired by cultural studies. Parker's aim, in this instance, is to provide an alternative to what he terms "linear, evolutionist accounts of urban development" (p. 233). He engages in a genealogical mode of analysis to chart how different disciplinary discourses are superseded at certain historical junctures. Parker's sources include literature, cinema and poetic readings and some of the works often cited in the field of cultural studies such as Berman (1983) and 
Davis (1992). He argues that a cyclical reading of the city in which connections are made between different episodes is more fruitful than linear histories or narratives that seek to portray the city as an outcome of sequential practices and events. On the surface, Parker's argument may appear to have only tangential relevance to our understanding of urban policy making. However, a close reading reveals some interesting ideas about how city life is conceptualised and the ways in which narratives establish an assemblage or contextual space in which policies are enacted.

Franklin (2001) also deploys a Foucauldian-inspired approach to examine competing perspectives on housing design and quality. Franklin argues that the built form has been neglected by writers drawing upon discourse analysis, in part because the physical component of housing is generally seen as the province of architecture and built environment disciplines. This neglect is addressed by examining texts on urban design published by government agencies and the building industry itself. In this respect her study provides an example of the new areas that can be explored using discourse analysis.

So far, all of the examples within this strand have been cited to illustrate the range and depth of the methodological approach. However, it should be pointed out that some works are more problematical. An example of a Foucauldian-inspired discourse analysis that exemplifies some of the concerns identified by critics is Vagnby and Jensen's (2002) analysis of changes in Danish urban policy. Though the authors set out to provide a discourse analysis, their study does not advance an explicit framework for analysis. Instead it provides an historical account of developments in policy, divided into three historical 'eras'. It is deficient in three respects. It does not explore power relations between different actors adequately; it does not provide sufficient social and political context to explain changes in policy; nor does it provide a sufficient description of the texts that have been used to develop the main arguments in the article. Vagnby and Jensen's article is one of many that claim to use discourse analysis methods, but disappoint the reader by failing to provide an adequate explanation of methods or by not revealing how these methods have informed the analysis.

Returning once again to Lees' distinction between different modes of discourse analysis-namely, the political economy and the Foucauldian-based scholarship-it should be evident from the above discussion that both strands have provided incisive commentaries on the urban policy process. At the risk of generalisation, the Foucauldian strand provides a firm basis for engaging in detailed archival scholarship and is perhaps best suited to more historical based analysis and for researchers who purport that discourse is a reflection of power relationships. The political economy strand of research (including work inspired by Fairclough and by discourse coalition theorists such as Dryzek, 1993 and Hajer, 1993) is more amenable to researchers keen to emphasise the material and economic factors that shape policy discourses and the recursive relationship between language and power. ${ }^{8}$

\section{Criticisms of Discourse Analysis}

Insufficient space prohibits a more detailed critique of the different traditions of discourse analysis. ${ }^{9}$ However, the following section explores the validity of some of the most common epistemological and practical criticisms of discourse analysis (in all its variants) made within the context of urban policy research. Certainly, there are examples to show that some of the researchers who foreground language are not always clear about their 
conceptual suppositions or explicit enough about their methods when conducting an analysis. Articles such as Vagnby and Jensen (2002), as already noted, require more detailed empirical evidence to back up some of the claims made.

Other objections frequently raised can be overcome. For example, it is not unusual for critics to dismiss discourse-based analysis as insular and of little practical relevance. Yet the different strands of discourse analysis have been instrumental in highlighting the way in which language is used in policy making and in providing a framework for critiquing contemporary practices. It is now common for media analysts to draw attention to the marketing of politics and the importance of presentation. In the UK, for example, the Labour Government's engagement with the media and the presentation of its policies have been explored in considerable detail (see Fairclough, 2000) and there is now a much greater public understanding of the ways in which governments seek to influence public opinion and to counteract public cynicism. It would be something of an exaggeration to claim that the increase in public awareness can be attributed entirely to the emergence of discourse analysis but it has certainly made an important contribution.

A second charge often made against discourse analysis is that it has limited utility in a practical context. For example, Lees (2004) argues that "it is a rather benign form of social scientific research", because in her view "it does not engage sufficiently with the promotion of social justice and therefore is rarely utilized by actors who engage in forms of urban activism" (p. 105). This accusation, that those who deploy a discursive analysis do not pay sufficient regard to the promotion of social justice, is surprising in that the charge is not only too sweeping a generalisation but also suggests a misunderstanding of what discourse analysis entails. Discourse analysis is primarily interpretative in that those who deploy its methods are seeking to foreground the pivotal role that language performs in the realms of politics and urban governance. Many of the writers who have deployed discourse analysis have generally sought to use the methodology as a means to highlight organisational inequalities and contested dynamics of power (e.g. Lemke, 1995; Rydin, 1998; Dean, 1999; Fairclough, 2000).

Similar and related accusations made against discourse analysis claim that it reduces all aspects of social life to discourse and that, because of its focus on language and text, those employing its methods very often fall into the trap of entangling ideas and concepts with those social and spatial practices that have a material existence independent of their discursive element (e.g. Imrie et al., 1996). This accusation is based upon a misunderstanding. It is now generally recognised that discourse itself has a material component and is part of a more complex set of social events (Van Dijk, 1997; McKenna, 2004). Furthermore, there is no claim that the material world or social structure do not exist and that everything is discourse (see Jacobs, 1999 for a discussion); rather it is our access to the material world that is mediated through discourse.

Furthermore, critics of discourse-based analysis often accuse its proponents of privileging individual agency and in particular subjectivity over structural factors arising from institutional practices and economic inequalities (e.g. Jessop, 1991; Badcock, 1996), thereby reducing complex phenomena to simplistic categories. This is an important criticism that proponents of discourse analysis have sought to overcome by contextualising individual agency in the wider political and economic context. Both Foucauldian and critical discourse-inspired research do not attempt to study texts in isolation but instead draw upon historical and other sources to make connections between the texts or utterances and wider social practices. 
Discourse analysis has also been accused of bias and distortion in that researchers who employ discourse-based methods select evidence that confirms their arguments and ignore contrary data. There is a tendency for some researchers who use a discourse-based approach to over-generalise and to infer too much from a particular example. The issue of whether or not a selection of a particular text can be representative is one that has bedevilled those engaged in discourse-focused research. A practical way to overcome this objection is to be explicit about the criteria for selecting discursive evidence and advancing a mode of analysis. It is also helpful when testing the validity of the interpretations advanced to explore the extent to which those agents operating in the field of enquiry accept the plausibility of the arguments advanced. Otherwise, as Goodchild and Cole (2001) warn, discourse-based approaches "risk degenerating into a confusing set of episodic narratives that cannot be put together" (p. 195).

Another accusation often levelled against the proponents of discourse analysis is that there are manifold interpretations as to what 'discourse' actually entails. There is a basis to this claim; as Fairclough et al. (2004) acknowledge, "many social research papers identify discourses in whatever material they are analysing without giving much indication of what particular features characterize a particular discourse" (p. 3). It is therefore incumbent on researchers to be explicit in regard to what they understand as constituting discourse, but futile to impose 'a one size fits all' definition. As both the terms 'discourse' and 'discourse analysis' are subject to competing definitions, it is useful to reiterate the same points already made by Hastings (2000); that is, linguists usually use the term 'discourse' to denote a single or groups of utterances or texts, while in social theory they are often used to make apparent the connection between language use and power relations. As Hastings identifies, an insightful way of understanding 'discourse' and 'discourse analysis' is propounded by Van Dijk (1997), in which 'discourse' is simply defined as "language use" and 'discourse analysis' as "the study of talk and text in context" (p. 3). ${ }^{10}$

\section{Future Possibilities}

What are the prospects for discourse analysis in the field of urban policy research? A number of conclusions can be drawn. It is evident from the criticisms made against discourse analysis that there are considerable challenges for the researcher seeking to deploy this methodology. In particular, researchers need to be aware and vigilant of the fact that urban policy texts are usually written for a particular audience and that this is the most important factor affecting the presentation of material as well as the imagery and language used. Also, in the area of policy work, most of the documents that are published

are sanitised; that is, they are written in such a way as to iron out any indication of disagreement or contestation. The majority of documents published in the area of urban policy are intended to convey a version of the policy process as linear and systematic. For the researcher interested in language, it is evident that policy texts are used as a way of regulating social interaction, in that they define rules and parameters of policy interaction.

At the start of this article two questions were posed: first, to what extent can discourse analysis provide insights into the policy process and second, to what degree are the criticisms made against discourse analysis justified? For discourse analysis to become a more influential method of research in the field of urban policy studies it will be necessary for its proponents to take a much more rigorous justification of its rationale than has sometimes been the case. In practice, this entails adopting a clear methodological 
framework that sets out the basis for the selection of texts and precise details of how the analysis is to be undertaken.

An explicit and clear approach is especially important if the methodology is to gain credibility and acceptance from the wider policy community. One of the biggest obstacles to this is the failure of some of the writers who deploy discourse methods to be precise about the terminology and to acknowledge the limitations of the methods. There is considerable scope for discourse analysis to be deployed as a supplementary tool to investigate some of the new and emerging issues within urban studies. However, for the methodology to have real purchase it is essential for researchers to write in a form that is accessible and to recognise its limitations.

The sample of articles summarised are testimony that discourse analysis as a methodological tool has considerable capacity to generate particular insights within urban policy. As already stated, Foucauldian-informed analysis is perhaps more appropriate for historically based archival research, whilst critical discourse analysis informed by Fairclough's work is especially suited to researchers keen to emphasise the recursive relationship between language and power and the importance of the economy on shaping policy discourses.

Finally, it is worth reflecting upon the future possibilities for urban policy research informed by discourse analysis. Four issues stand out. First, there is considerable scope for researchers to examine the ways in which certain words, currently prevalent in urban policy discourse, are deployed by policy makers. For example, terms such as 'sustainability', ${ }^{11}$ 'housing affordability' and 'regeneration' are widely used in the contemporary urban policy agenda, yet have only been subject to limited critical scrutiny. Discourse analysis offers an explicit basis to interrogate these and other terms and to show how they are deployed by policy makers at a strategic and ideological level.

Second, one of the most exciting developments in recent years has been the increasing technologisation of urban policy making. Innovations in computer technology in particular have heralded new possibilities for developing policy community networks, modes of consultation and decision making (see Amin \& Thrift, 2002). Already, urban policy making is affected by new developments that necessitate further sociological investigation and interrogation. There are good reasons to be optimistic that discourse analysis can help us understand these developments in more informed ways than has hitherto been the case, on account of its explicit commitment to contextualise the practices of communication exchange and interaction.

Third, as this brief survey of urban policy research informed by discourse-based research has shown, much of the research that has been undertaken has concentrated on the production of texts and the ways in which organisations use documents to promote a particular version of the policy agenda. There have been very few examples of research that focuses on reception - that is, the way in which texts and policy documents are interpreted by different policy audiences (for an example see Smith, 1999). The main reason for this lacuna is practical, since making contact with consumers of contemporary policy texts is time consuming and necessitates bringing together a representative group audience to discuss specific publications. Nonetheless, it is an area worthy of analysis.

Fourth, this article has primarily focused on written texts, but some of the most innovative work has extended the methods usually associated with a textual based discourse analysis to other areas, for example, visual representations of the city and architecture. ${ }^{12}$ There are clearly exciting possibilities for researchers to use the methods 
associated with discourse analysis to develop new research areas relevant to urban policy, for example, the visual marketing of city neighbourhoods by government agencies.

In conclusion, a close scrutiny of texts and performative language offers a valuable resource for the applied social science researcher, by enabling important insights about the conduct of urban policy. At its best, research that draws upon the methods of discourse analysis provide the reader with a theoretically informed, carefully argued and nuanced account of urban policy. However, the selection and scrutiny of the evidence base has an important bearing on the utility of the analysis advanced. For this reason, it is important that researchers who deploy these methods are vigilant when selecting the evidence for the analysis and careful not to over-generalise, especially when the evidence base is limited. However, so long as researchers remain vigilant to these issues, studies that draw upon the methods of discourse analysis will continue to be valued for the insights generated and the lucidity of arguments advanced.

\section{Acknowledgements}

The author would like to express his thanks to the two anonymous referees for their helpful comments on an earlier version of this article.

\section{Notes}

1. At this juncture, it is important to note that discourse analysis is best understood as a methodology that highlights the importance of language, within which a range of methods are deployed.

2. Evidence for a burgeoning interest in discourse analysis was provided by the publication in 1999 of a special issue of the Urban Studies journal entitled "Discourse and Urban Studies". The special issue contained 12 articles.

3. In an article of this size it is not possible to provide a comprehensive review of all the recent literature of urban policy research informed by discourse analysis. In my selection I have, in the main, chosen texts that shed light on the policy process.

4. For a discussion on Connolly's influence on the study of politics see Yeatman (1990).

5. A clear summary of Laclau and Mouffe's mode of discourse analysis is provided by Howarth (1995).

6. A reason for this may be that Foucault himself did not provide an explanation as to how a discourse analysis should proceed.

7. Whilst making these observations, it is important to note that they apply to this article only and not to some of the other works authored by Jensen in the area of discourse, for example, Jensen (1997) and Richardson and Jensen (2003).

8. See Hastings (1999) for a discussion of the differences between Fairclough and Foucauldian-inspired discourse analysis.

9. The different strands and criticisms of discourse analysis are presented in considerable detail in Andersen (2003).

10. Other papers that discuss the criticisms made against discourse analysis include Jacobs and Manzi (1996), Jacobs (1999), Collins (2000), Hastings (2000), Marston (2002) and Jacobs (2004).

11. An exception is the work of Rydin (1998).

12. Chaplin (1994) and Rose (2001) provide useful ways in which researchers can study visual productions in a systematic way.

\section{References}

Amin, A. \& Thrift, N. (2002) Cities: Reimagining the Urban (Cambridge: Polity Press).

Andersen, N. (2003) Discursive Analytical Strategies (Bristol: Policy Press).

Antaki, C., Billig, M., Edwards, D. \& Potter, J. (2002) Discourse analysis means doing analysis: a critique of six analytic shortcomings, Discourse Analysis Online. Available at www.shu.ac.uk/daol/articles/open/2002/ 002/antaki2002002-paper.html 


\section{$50 \quad$ K. Jacobs}

Arapoglou, V. (2004) The governance of homelessness in Greece: discourse and power in the study of philanthropic networks, Critical Social Policy, 2(1), pp. 102-126.

Atkinson, R. (1999) Discourses of partnership and empowerment in contemporary British urban regeneration, Urban Studies, 36(1), pp. 59-72.

Badcock, B. (1996) 'Looking glass' views of the city, Progress in Geography, 20, pp. 91-99.

Beauregard, R. (1993) Voices of Decline: The Postwar Fate of US Cities (Cambridge, MA: Blackwell).

Berman, M. (1983) All that is Solid Melts into Air (London: Verso).

Billig, M. (1995) Banal Nationalism (London: Sage).

Boyle, M. \& Rogerson, R. (2001) Power discourses and city trajectories, in: R. Paddison (Ed.) Handbook of Urban Studies, pp. 402-416 (London: Sage).

Chaplin, E. (1994) Sociology and Visual Representation (London: Routledge).

Collins, C. (2000) Developing the linguistic turn in urban studies: language, context and political economy, Urban Studies, 37(11), pp. 2027-2043.

Connolly, W. (1983) The Terms of Political Discourse (Princeton, NJ: Princeton University Press).

Davis, M. (1992) Fortress Los Angeles: the militarization of urban space, in: M. Sorkin (Ed.) Variations on a Theme Park, pp. 154-180 (New York: Hill and Wang).

Davoudi, S. \& Healey, P. (1995) City challenge: sustainable process or temporary gesture?, Environment and Planning C: Government and Policy, 13(1), pp. 79-95.

Dean, M. (1999) Governmentality: Power and Rule in Modern Society (London: Sage).

Dryzek, J. (1993) Policy analysis and planning: from science to argument, in: F. Fischer \& J. Forester (Eds) The Argumentative Turn in Policy Analysis and Planning, pp. 213-232 (London: UCL Press).

Edwards, D. (1997) Discourse and Cognition (London and Beverly Hills, CA: Sage).

Fairclough, N. (1989) Language and Power (London: Longman).

Fairclough, N. (1992) Discourse and Social Change (Cambridge: Polity Press).

Fairclough, N. (1995) Critical Discourse Analysis (London: Longman).

Fairclough, N. (2000) New Labour New Language? (London: Routledge).

Fairclough, N., Graham, P., Lemke, J. \& Wodak, R. (2004) Introduction, Critical Discourse Studies, 1(1), pp. 1-7.

Fischer, F. \& Forester, J. (Eds) (1993) The Argumentative Turn in Policy Analysis and Planning (London: UCL Press).

Foucault, M. (1971) Madness and Civilisation (London: Routledge).

Foucault, M. (1972) The Archaeology of Knowledge (New York: Pantheon Books).

Foucault, M. (1974) The Order of Things: An Archaeology of the Human Sciences (London: Tavistock).

Foucault, M. (1977) Discipline and Punish (London: Penguin).

Foucault, M. (1980) Power/Knowledge: Selected Interviews and Other Writings 1972-1977 (Brighton: Harvester).

Foucault, M. (1991) Governmentality, in: G. Burchell, C. Gordon \& P. Miller (Eds) The Foucault Effect: Studies in Governmentality, pp. 87-104 (Hemel Hempstead: Harvester).

Franklin, B. (2001) Discourses of design: perspectives on the meaning of housing quality and 'good' housing design, Housing Theory and Society, 18(1/2), pp. 79-92.

Goodchild, B. \& Cole, I. (2001) Social balance and mixed neighbourhoods in Britain since 1979, Environment and Planning B, 19(2), pp. 191-211.

Hajer, M. (1993) Discourse coalitions and the institutionalisation of practice: the case of acid rain in Great Britain, in: F. Fischer \& J. Forester (Eds) The Argumentative Turn in Policy Analysis and Planning, pp. 43-76 (London: UCL Press).

Hall, S. (1988) Thatcherism and the Crisis of the Left: The Hard Road to Renewal (London: Verso).

Harrison, C., Munton, R. \& Collins, K. (2004) Experimental discursive spaces: policy processes, public participation and the Greater London Authority, Urban Studies, 41(4), pp. 903-918.

Hastings, A. (1998) Connecting linguistic structures and social practices: a discursive approach to social policy analysis, Journal of Social Policy, 27(2), pp. 191-211.

Hastings, A. (1999) Introduction, 'Special Issue: Discourse and Urban Change', Urban Studies, 36(1), pp. 7-12.

Hastings, A. (2000) Discourse analysis: what does it offer housing studies, Housing, Theory and Society, 17(3), pp. $131-139$.

Howarth, A. (1995) Discourse theory, in: D. Marsh \& G. Stoker (Eds) Theory and Methods in Political Science, pp. 115-136 (Basingstoke: Macmillan).

Imrie, R., Pinch, S. \& Boyle, M. (1996) Identities, citizenship and power cities, Urban Studies, 33(8), pp. $1255-1261$. 
Jackson, N. (1999) The council tenants' forum: a liminal public space between lifeworld and system?, Urban Studies, 36(1), pp. 43-58.

Jacobs, K. (1999) Conclusion, 'Special Issue: Discourse and Urban Change', Urban Studies, 36(1), pp. $203-213$.

Jacobs, K. (2004) Waterfront redevelopment: a critical discourse analysis of the policy making process within the Chatham Maritime project, Urban Studies, 41(4), pp. 817-832.

Jacobs, K. \& Manzi, T. (1996) Discourse and policy change: the significance of language for housing research, Housing Studies, 11(4), pp. 543-560.

Jensen, O. (1997) Discourse analysis and socio-spatial processes transformation processes: a theoretical framework for analysing spatial planning, Working Paper No. 61, Department of Town and Country Planning, University of Newcastle upon Tyne.

Jessop, B. (1991) Foreword, in: R. Bertramsen, J. Peter, F. Thomsen \& J. Torfing (Eds) State, Economy and Society, pp. xiv-xxvii (London: Unwin Hyman).

Klodawsky, F., Farrell, S. \& D’Aubry, T. (2002) Images of homelessness in Ottawa: implications for local politics, Canadian Geographer, 46(2), pp. 126-143.

Laclau, E. \& Mouffe, C. (1985) Hegemony and Socialist Strategy (London: Verso).

Lees, L. (2004) Urban geography: discourse analysis and urban research, Progress in Human Geography, 28(1), pp. 101-107.

Lemke, J. (1995) Textual Politics: Discourse and Social Dynamics (London: Taylor \& Francis).

Marston, G. (2002) Critical discourse analysis and policy-orientated housing research, Housing Theory and Society, 19(2), pp. 82-91.

Marston, G. (2004a) Managerialism and public housing reform, Housing Studies, 19(1), pp. 5-20.

Marston, G. (2004b) Social Policy and Discourse Analysis (Aldershot: Ashgate).

McKenna, B. (2004) Critical discourse studies: where to from here, Critical Discourse Studies, 1(1), pp. 9-39.

Mele, C. (2000) The materiality of urban discourse - rational planning in the restructuring of the early twentieth century ghetto, Urban Affairs Review, 5, pp. 628-648.

Newman, I. (1996) Discourse and the public sector, Local Government Policy Making, 23, pp. 52-59.

Parker, I. \& Burman, E. (1993) Against discursive imperialism, empiricism and constructionism: thirty two problems with discourse analysis, in: E. Burman \& I. Parker (Eds) Discourse Analytic Research: Repertoires and Readings of Texts in Action, pp. 155-172 (London: Routledge).

Parker, S. (2000) Tales of the city: situating urban discourse in place and time, City, 4(2), pp. 223-246.

Potter, J. (1996) Representing Reality: Discourse, Rhetoric and Social Constructionism (London: Sage).

Potter, J. (2003) Discourse analysis and discursive psychology, in: P. Camic, J. Rhodes \& L. Yardley (Eds) Qualitative Research in Psychology: Expanding Perspectives in Methodology and Design, pp. 73-94 (Washington: American Psychological Association).

Richardson, T. (2004) Interface Planning Theory and Practice, 5(4).

Richardson, T. \& Jensen, B. (2003) Linking discourse and space: towards a cultural sociology of space in analysing spatial policy discourses, Urban Studies, 40(1), pp. 7-22.

Rose, G. (2001) Visual Methodologies (London: Sage).

Rydin, Y. (1998) The enabling local state and urban development: resources, rhetoric and planning in East London, Urban Studies, 35(2), pp. 175-191.

Sharp, E. \& Richardson, T. (2001) Reflections on Foucauldian discourse analysis in planning and environmental policy research, Journal of Environmental Policy and Planning, 3(3), pp. 193-209.

Skillington, T. (1998) The city as text: constructing Dublin's identity through discourse on transportation and urban redevelopment in the press, British Journal of Sociology, 49(3), pp. 456-473.

Smith, F. (1999) Discourses of citizenship in transition: scale, politics and urban renewal, Urban Studies, 36(1), pp. $167-187$.

Stenson, K. \& Watt, P. (1999) Governmentality and 'the death of the social'?: a discourse analysis of local government texts in south-east England, Urban Studies, 36(1), pp. 189-201.

Stone, D. (1988) Policy, Paradox and Political Reason (Glenview, IL: Scott Foresman).

Taylor, M. (1999) Unwrapping stock transfers: applying discourse analysis to landlord communication strategies, Urban Studies, 36(1), pp. 121-135.

Vagnby, B. \& Jensen, O. (2002) From slum clearance to urban policy: discourse and doctrines in Danish inner city redevelopment, Housing Theory and Society, 19(1), pp. 3-13.

Van Dijk, T. (1997) The study of discourse, in: T. Van Dijk (Ed.) Discourse as Structure and Process, Vol. 1, pp. 1-34, 1 (London: Sage).

Volosinov, V. (1986) Marxism and the Philosophy of Language (Cambridge, MA: Haward University Press). 


\section{K. Jacobs}

Wetherell, M., Taylor, S. \& Yates, S. (Eds) (2001) Discourse as Data: A Guide for Analysis (London: Sage).

Winch, P. (1977) The Idea of a Social Science and its Relation to Philosophy (London: Routledge).

Wittgenstein, L. (1974) Philosophical Investigations (Oxford: Blackwell).

Wodak, R. \& Meyer, M. (2001) Methods in Critical Discourse Analysis (London: Sage).

Yeatman, A. (1990) Bureaucrats, Technocrats and Femocrats: Essays on the Contemporary Australian State (Sydney: Allen and Unwin). 